Editorial

\title{
Study of Serum ferritin levels in $\beta$-Thalassemia major children
}

\author{
Koreti S. ${ }^{1}$, Gaur B.K. ${ }^{2}$, Das G. ${ }^{3}$, Gaur A. ${ }^{4}$ \\ ${ }^{1}$ Dr. Sunita Koreti ${ }^{1}$, Professor, Department of Pediatrics, Kamala Raja Hospital, G.R Medical College Gwalior, Madhya \\ Pradesh, India, ${ }^{2}$ Dr. Bablu Kumar Gaur, Assistant Professor, Department of Pediatrics, Maharishi Markandeshwar \\ Institute of Medical Sciences and Research, Mullana, Ambala, Haryana, India, ${ }^{3}$ Dr. Ghanshyam Das, Professor, \\ Department of Pediatrics, Kamala Raja Hospital, G. R Medical College Gwalior, Madhya Pradesh, India, ${ }^{4}$ Dr. Ajay Gaur, \\ Professor \& Head, Department of Pediatrics, Kamala Raja Hospital, G.R Medical College Gwalior, Madhya Pradesh, \\ India.
}

Correspondence Author: Dr. Bablu Kumar Gaur, Assistant Professor, Flat No- 11, E Block, M.M Residential Complex, MMU, Mullana, Ambala (Haryana).E-mail ID-drbkgaur@gmail.com

\begin{abstract}
Background: Thalassemiais one of the most common inherited single-gene disorder in the world. Every year approximately 100,000 thalassemia major children are born all over the world, and there are about 65,000-67,000 $\beta$ thalassemia major patients in India, with around 9,000-10,000 cases being added every year. Measurement of serum ferritin level can give idea regarding starting of Iron chelation therapy, which will reduce the concentration of serum ferritin and effective in preventing iron induced tissue injury and prolonging life expectancy. Method: This study was conducted on 60 children between 3 to 17 years, being regularly transfused at department of Pediatrics, Kamala Raja Hospital, Gajra Raja Medical College, Gwalior, for period of 1 year from 2011 to 2012, after taking the informed consent from the parents and explaining them the purpose of study. Detailed history weretaken and serum ferritin level weremeasured by ELISA based serum ferritin assay kit. Results: Serum ferritin level was found to be elevated in all the patients of beta thalassemia major with range from 1050 to $5029 \mu \mathrm{g} / 1$ and with a mean value of $3879 \mu \mathrm{g} / 1$. Out of 60 patients, $30(50 \%)$ patients had serum ferritin level below $2000 \mu \mathrm{g} / 1,20(33.3 \%)$ patients had serum ferritin value between 2001 to $4000 \mu \mathrm{g} / 1$ and rest 10 (17.7\%) patients had values above $4000 \mu \mathrm{g} / \mathrm{l}$. Mean value of serum ferritin was found to be higher in patients who received frequent blood transfusion. Conclusion: Majority of the patients had very high ferritin levels, with a mean value of $3879 \mu \mathrm{g} / 1.50 \%$ patients had serum ferritin levels more than $2000 \mu \mathrm{g} / \mathrm{l}$. This cut off value reflect either inadequate chelation therapy or non-affordability of parents to purchase oral chelation therapy.
\end{abstract}

Key words: $\beta$-Thalassemia major, Serum ferritin, Blood transfusion

\section{Introduction}

Thalassemia is one ofthe most common inherited single-gene disorder in the world. Reportedly there are about 240 million carriers of beta thalassemia world wide and in India alone, the number is approximately 30 million with a mean prevalence of $3.3 \%$. Every year approximately 100,000 thalassemia major children are born all over the world, and there are about 65,000$67,000 \beta$ thalassemia major patients in India, with around 9,000-10,000 cases being added every year[1,2]

The name Thalassemia is derived from a combination of two Greek words: Thalassa meaning the sea, i.e. the Mediterranean, and anemia ("weak blood")[3]. It is characterized by deficient or absent synthesis of normal

Manuscript received: $28^{\text {th }}$ May 2018

Reviewed: $6^{\text {th }}$ June 2018

Author Corrected: $14^{\text {th }}$ June 2018

Accepted for Publication: $20^{\text {th }}$ June 2018 globin chains owing to inherited mutations of $\beta$ - globin genes, where more than 200 mutations, mostly point mutations are seen in $\beta$ thalassemia. There is an excess of alpha globin chains relative to beta and gamma globin chains and alpha globin tetramer formed that cause damage to both developing $\mathrm{RBC}$ and mature RBC. The gamma and delta globin are produced in increased amount leading to an elevated $\mathrm{HbF}$ and $\mathrm{HbA2}$. Since $\beta$ chains are not present in fetal hemoglobin, beta thalassemia major does not manifest itself in newborns. Beta thalassemia presents at 6 months of age when adult hemoglobin has replaced fetal hemoglobin.

The clinical course is characterized by severe anemia, failure to thrive, typical facies (also called chipmunk facies/thalassemic facies), marked hepatosplenomegaly, 
Editorial

cachexia and pathological bone fractures [4]. The most effective approach to reduce the burden on the society and reduce the disease incidence is through implementation of a carrier-screening programs offering genetic counseling, prenatal diagnosis and selective termination of affected fetus [5].

The liver is the major site of iron overload, containing $70 \%$ or more of body iron content. Liver iron correlates closely with total body iron in Transfusional iron overload.

Estimation of direct liver iron concentration is the most accurate method of estimation of iron overload. But in our set up this method was not available. Indirect method with serum ferritin level measurement is reliable, easy to perform, low cost, and had no side effects [6].

Cure of beta thalassemia major is available with bone marrow transplantation but because of lack of facility, affordability and awareness, cure of these children is very difficult; so now a day's regular blood transfusion and continuous iron-chelation therapy is the mainstay of treatment available for these children.

In India, most thalassemic children are under transfused and do not get appropriate Iron-chelation therapy because the cost of treating a thalassemia child is approximately one lakh per year.

The aim of the present study is to assess the serum ferritin levels in multi-transfused $\beta$ Thalassaemia major patients, so that timely corrective measures can be adopted.

\section{Material \& Methods}

Study design- Prospective and hospital-based study.

Study center- Department of Pediatrics, Kamala Raja Hospital, Gajra Raja Medical College, Gwalior, Madhya Pradesh, India.

Period of study- June 2011 to June 2012

Study population- This studywas conducted on 60 confirmed $\beta$ thalassemia major children between 3 to 17 years, registered in Gwalior thalassemia society, being regularly transfused at department of Pediatrics, Kamala Raja Hospital, G R Medical College, Gwalior.

Ethical clearance was obtained from the institutional ethical committee.
Sample collection- The known cases of $\beta$ thalassemia major children between 3-17 years, that had been transfused in Kamala Raja Hospital were selected by purposive sampling method. Subjects were classified into three age groups: $3-5 y$ years, in between $6-10$ years and $11-17$ years.

\section{Inclusion criteria}

- Child suffering from $\beta$-thalassemia major only as confirmed by Hbelectrophoresis.

- Age of thalassemic child should be between 3-17 years.

- Attending department of pediatrics, Kamala Raja Hospital, Gajra Raja Medical College, Gwalior.

\section{Exclusion criteria}

- Abnormal liver functions.

- Presence of infections at the time of sample collection,

- Any haemoglobinopathy other than beta thalassemia major.

Methodology and Sampling methods: Detailed history (age, sex, history of blood transfusion, history of iron-chelation therapy) as per the proforma was taken. $3 \mathrm{ml}$ of blood was collected by vein puncture and allowed to clot. The separated serum was used for the estimation of ferritin levels using ELISA based serum ferritin assay kit (Acculite ferritin kit) by chemilumine scence immunoassay method.

Principle of serum ferritin estimation: The essential reagents required include high affinity and specific antibodies, with different and distinct epitope recognition, in excess and native antigen. In this procedure, the immobilization takes place during the assay at surface of an opaque chemiluminescent reaction cell through the interaction of streptavidin coated on the opaque reaction cell exogenously added biotinylated monoclonal antibody coupled to the analyte of interest. upon mixing monoclonal biotinylated antibody, the enzyme labeled antibody and test serum containing the native antigen and the antibody, without competition, to form a soluble sandwich complex.

Statistical Analysis: All the statistical analysis were conducted by using Epi Info ${ }^{\mathrm{TM}}$ software version 3.5.3. Data were analyzed to determine association between variables. The association between age, sex, frequency of blood transfusion and serum ferritin level were established. Chi-square test was used to compares the groups. A two-tailed pvalue of $<0.05$ was considered to be statistically significant. 


\section{Results}

This study included 60 patients suffering from beta thalassemia major, with 11 (18.3\%) females and 49 (81.7\%) males. The study subjects were classified into three age groups: 3-5 years, 6 -10 years and 11-17 years (Table-1). The mean age was $9.45 \pm 4.9$ years with a range of 3-17 years. The median age at the first transfusion was six months (range 4-16 months), The most frequently observed patients were Sindhi $(86 \%)$, followed by the Muslim $(10 \%)$ and Others (4\%). Blood group analysis revealed Group $\mathrm{O}$ to be the most common amongst our sample (45\%). A positive family history of thalassemia major was recorded in $67.5 \%$ of the patients, and $55.5 \%$ of them gave a history of consanguineous marriage of parents. History of splenectomy was found in $10(17.7 \%)$ children.

Table-1: Age and sex wise distribution of beta thalassemia major patients.

\begin{tabular}{|c|c|c|c|}
\hline \multirow{2}{*}{$\begin{array}{c}\text { Age group } \\
\text { (in years) }\end{array}$} & Male & Tex of children & \multirow{2}{*}{ Total } \\
\cline { 2 - 4 } & 25 & 4 & 29 \\
\hline $3-5$ & 10 & 4 & 14 \\
\hline $6-10$ & 14 & 3 & 17 \\
\hline
\end{tabular}

Out of total 60 children, most were in the age group of 3 to 5 years.

The mean serum ferritin concentration was $3879 \mu \mathrm{g} / 1$ (range $1050-5029 \mu \mathrm{g} / \mathrm{l}$ ). Mean serum ferritin of children aged between 3-5 years was $1667 \pm 297$, while in children of more than 10 years mean serum ferritin was $3744 \pm 715$.

Table-2: Age wise distribution of mean serum ferritin level in beta thalassemia major patients.

\begin{tabular}{|c|c|c|}
\hline Age group(in years) & Serum ferritin (Mean \pm SD) & Total patients \\
\hline $3-5$ & $1667 \pm 297$ & 29 \\
\hline $6-10$ & $2675 \pm 719$ & 14 \\
\hline $11-17$ & $3744 \pm 715$ & 17 \\
\hline
\end{tabular}

The serum ferritin concentration was less than $2000 \mu \mathrm{g} / 1$ in 30 patients $(50 \%)$, between $2001-4000 \mu \mathrm{g} /$ in 20 patients $(33.3 \%)$ and rest 10 patients $(17.7 \%)$ had serum ferritin levels $>4000 \mu \mathrm{g} / 1$. Majority of the patients with high serum ferritin concentration $(>4000 \mu \mathrm{g} / \mathrm{l})$ were aged more than 10 years (Fig-1). Mean serum ferritin concentration of the females patients was $2986 \mu \mathrm{g} / \mathrm{lwhile}$ in male patients it was $3245 \mu \mathrm{g} / \mathrm{l}$. There was no significant difference of mean serum ferritin concentration between two groups $(\mathrm{p}=0.54)$.

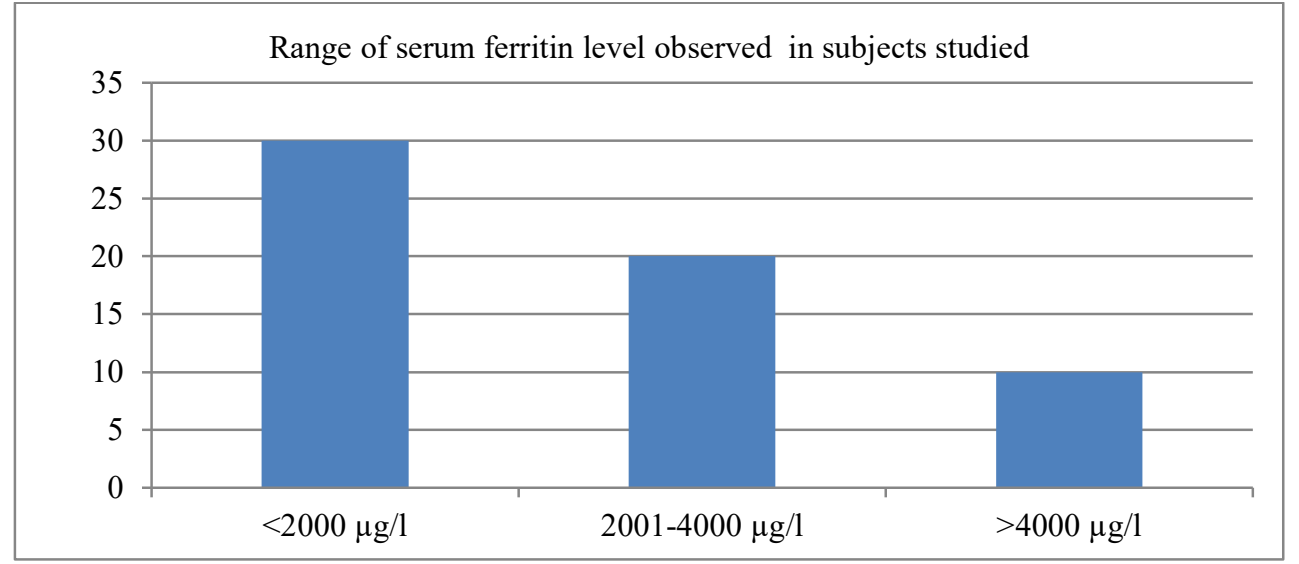

Figure-1: Range of serum ferritin level observed in beta thalassemia major patients

Serum ferritin values were analysed based on average total number of transfusions. Patients with transfusion more than 150 times had ferritin level greater than the patients who had transfusions less than 150 times and this difference was statistically significant ( $\mathrm{p}$ value $<0.001)($ Table-3). 
Editorial

Table-3: Correlation between mean serum ferritin level and number of blood transfusions

\begin{tabular}{|c|c|c|}
\hline Number of blood transfusions & Serum.ferritin (mean \pm sd) & p.value \\
\hline$<150$ & $2109 \pm 734$ & $<0.001$ \\
\hline$>150$ & $3956 \pm 925$ & \\
\hline
\end{tabular}

Patients with transfusion more than 150 times had ferritin level greater than the patients who had transfusions less than 150 times and this difference was statistically significant ( $p$ value $<0.001$ )

Out of 60 children $42(70 \%)$ were taking some form of oral chelation therapy, rest $18(30 \%)$ children were not receiving chelation therapy. Fig-2 showed a linear relationship between the age of thalassemia major patients and total number of blood transfusions received so far. With the increase in age, the cumulative number of blood transfusions received will increase, as is depicted in the graph.

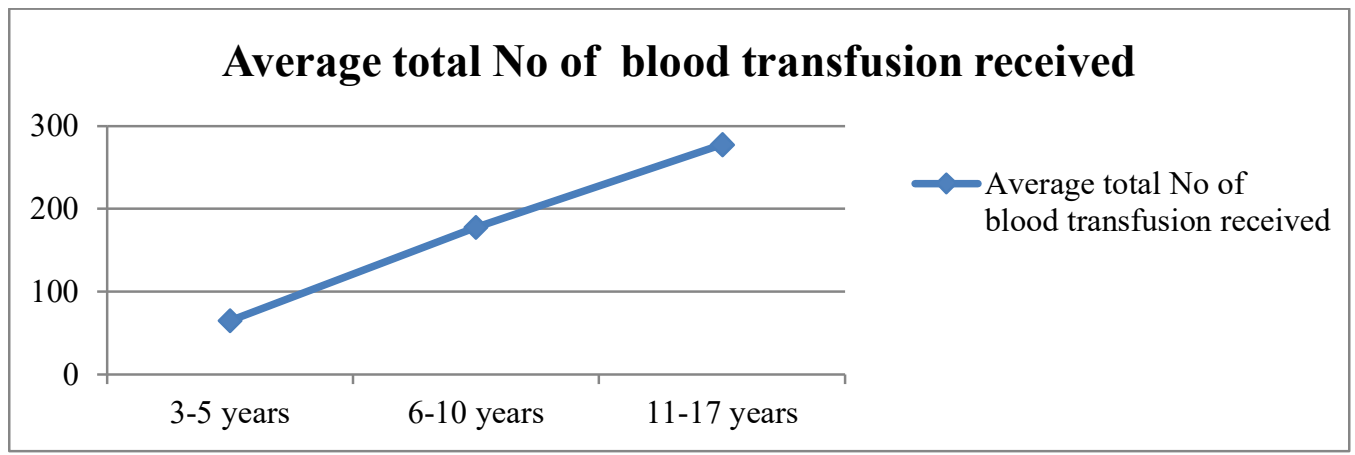

Fig-2: Age group wise average total no of blood transfusion in beta thalassemia major children

Graphshows a linear relationship between the age of thalassemia major patients and average total number of blood transfusions

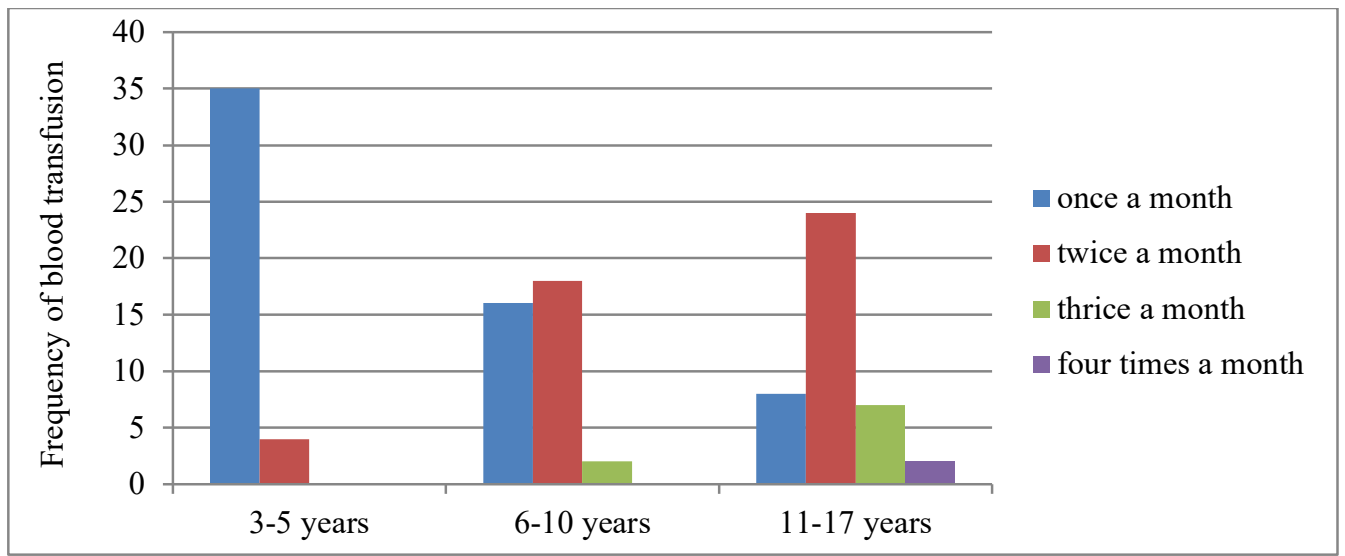

Fig-3 showed that frequency of blood transfusions received per month also goes up.

Most of the patients aged 3-5 years receive blood transfusions only once a month.

Most of the beta thalassemia major children age group 3-5 years, received blood transfusions only once a month, while children in 6-10 years and 11-17 years age group, received blood transfusion twice or thrice a month (Fig-3)

\section{Discussion}

Thalassemia is one of the commonest hemolytic anemia in India. Serious complications due to iron overload still occurs in Thalassemia. Transfusional hemosiderosis is the major cause of late morbidity and mortality inpatients with thalassemia major. It can be prevented by use of iron-chelation therapy which will reduce the concentration of serumferritin and is effective in preventing iron induced tissue injury and prolonging life expectancy. 
Editorial

Parameters used to monitor iron overload include serum ferritin, liver biopsy, SCQID, and $\mathrm{T}_{2}$ MRI assessment of liver and cardiac iron, in conjunction with functional testing such as echocardiography and measures of endocrine function. Dual energy CT for measurement of liver iron has also been performed in some centres [7]. Each of these parameters has a different role. While Serum ferritin is the most commonly used parameter for monitoring iron overload [8]. It correlates with cardiac impairment and survival [9] but can be elevated by many confounding factors, including acute phase reactions such as infections, inflammation or malignancy, or by hepatic damage. The study group comprised of 60 children of $\beta$ thalassemia major being regularly transfused at department of Pediatrics, Kamla Raja Hospital, G.R Medical College, Gwalior. Out of the $60 \beta$ thalassemia major patients, 29 patients belong to age group 3-5 years, 14 patients belong to age group 6-10 years, and 17 patients belong to age group 11-17 yrs. Males 49 (81\%) were more than females 11(19\%), similar to the result obtained by Torres et al[10]Najafipour et al[11] and Nadeem Ikran et al[12] in which the males were $60 \%, 64 \%$ and $64 \%$ and females were $40 \%, 36 \%$ and $36 \%$ respectively.

Serum ferritin level was found to be elevated in all the patients of betathalassemia major with range from 1050 to 5029 $\mu \mathrm{g} / \mathrm{l}$ with a mean value of $3879 \mu \mathrm{g} / \mathrm{l}$. The age of patients at the time of diagnosis ranged from 4 months to 16 months with a mean of 10 months. The interval between successive transfusions varied between one weak to four weeks in different patients. Nadeem Ikran et al (2004)[12] conducted study to know the levels of serum ferritin in patients of beta thalassemia. In a total of 75 cases of thalassaemia major studied in this series, 48 were males and 27 females with a male to female ratio of 1.77: 1 . The age of patients at the time of diagnosis ranged from 6 months to $2 \frac{1}{2}$ years with a mean of 1 year and 4 months. The age at the time of this study ranged between 2 years 5 months to 21 years. The interval between successive blood transfusions varied between 7 days to 5 weeks in different patients. the frequency of transfusion had gradually increased. The mean serum ferritin levels were $3390+135.6 \mathrm{ng} / \mathrm{ml}$. Only two patients $(2.67 \%)$ had serum ferritin levels of less than $1000 \mathrm{ng} / \mathrm{ml}$. Sixteen patients (21.34\%) had serum ferritin levels between $1000-2500 \mathrm{ng} / \mathrm{ml}$, while 57 patients $(76 \%)$ had values more than $2500 \mathrm{ng} / \mathrm{ml}$. Results are almost similar to our study.

Table-4: Summary of the studies showing mean serum ferritin levels in beta thalassemia major patients:-

\begin{tabular}{|c|c|c|c|c|}
\hline S No. & Author & Country & Year & Mean serum ferritin level( $\boldsymbol{\mu g} / \mathbf{l})$ \\
\hline 1. & NadeemIkran et al [12] & Pakistan & 2004 & $3390 \mu \mathrm{g} / 1$ \\
\hline 2. & Lucas et al[13] & Sri-lanka & 2000 & $5743 \mu \mathrm{g} / 1$ \\
\hline 3. & Shah et al[14] & Western India & 2010 & $3456 \mu \mathrm{g} / 1$ \\
\hline 4. & Al Jaouni et al[15] & Saudi Arebia & 2010 & $3272.5 \mu \mathrm{g} / 1$ \\
\hline 5. & Cunningham et al[16] & North America & 2004 & $1696 \mu \mathrm{g} / 1$ \\
\hline 6. & Choudhry VP et al[17] & India & 2004 & $6723 \mu \mathrm{g} / 1$ \\
\hline 7. & Riaz et al[18] & Pakistan & 2011 & $4236 \mu \mathrm{g} / 1$ \\
\hline 8. & Rehman M et al[19] & Pakistan & 2004 & $2861 \mu \mathrm{g} / 1$ \\
\hline 9. & Present study & Gwalior, India & 2012 & $3879 \mu \mathrm{g} / 1$ \\
\hline
\end{tabular}

\section{Conclusion}

Majority of the patients had very high ferritin levels, with a mean value of $3879 \mu \mathrm{g} / 1$. $50 \%$ patients had serum ferritin levels more than $2000 \mu \mathrm{g} / \mathrm{l}$. Thus it can be concluded from the present study that serum ferritin concentration which is considered to be a marker for liver iron concentration was found to be increased in all the beta thalassemia major patients. serum ferritin is a easy, cost effective and best indirect test for determination of iron overload.

\section{What this study adds to existing knowledge?}

Iron chelation therapy should be start when serum ferritin level exceeds $1000 \mu \mathrm{g} / \mathrm{L}$, with the aim of keeping serum ferritin levels below $1000 \mu \mathrm{g} / \mathrm{Lto}$ avoid the systemic effects of iron overload.

\section{Contributions}

- Dr Sunita Koreti and Dr Bablu Kumar Gaurwrote first draft of the manuscript.

- Dr G Das and Dr Ajay Gaurhelped in supervised data collection and analysis.

- Dr Bablu Kumar Gaur made final correction of manuscript before submission.

- All authors approved submission of the manuscript and own responsibility of the manuscript.

- None of the authors have any conflict of interest.

Ethical approval-obtained

Acknowledgement: Wish to place my deep sense of gratitude and gratefulness to the guiding light and pillar of my strength, my esteemed teacher, Dr Ajay Gaur, 
Editorial

Professor and Head, Department of Pediatrics, GRMC Gwalior, who has always been a source of immense inspiration. I express my deep sense of obligation to all my beta thalassemic patients who cooperated with me and silently made their invaluable contribution to medical science.

Funding: Nil, Conflict of interest: None initiated, Perission from IRB: Yes

\section{References}

1. Yaish HM. Thalassemia. http://www.emedicine. Com / PED/ topic2229.htm Accessed 6th August 2007.

2. Verma IC, Choudhry VP, Jain PK. Prevention of thalassemia: a necessity in India. Indian J Pediatr. 1992 Nov-Dec;59 (6): 649-54.

3. Cooley TB, Lee P: A series of cases of splenomegaly in children with anemia and peculiar bone changes. Trans Am Pediatr Soc 1925;37:29 -30.

4. Debaun MR, Vinchisky E. Hemoglobinopathies. In: Kliegman, Behrman, Jenson, Stanton, editors. Nelson textbook of Pediatrics. 18th ed. Philadelphia: Elsevier; 2008.

5. Maheshwari M, Arora S, Kabra M, et al. Carrier screening and prenatal diagnosis of beta-thalassemia. Indian Pediatr. 1999 Nov;36(11):1119-25.

6. Olivieri NF, Brittenham GM. Iron-chelating therapy and the treatment of thalassemia. Blood.1997 Feb 1;89 (3) : 739-61.

7.Suvarna J, Ingle H, Deshmukh CT. Insulin resistance and betacell function in chronicallytransfused patients of thalassemia major. Indian Pediatr. 2006 May; 43 (5):393-400..

8. Brittenham GM, Farrell DE, Harris JW, et.al. Magnetic-susceptibility measurement of human iron stores. DOI:10. 1056/NEJM198212303072703

9. Arrigo T, Crisafulli G, Meo A, Sturiale M, Combardo F. Micelli, Cucinotta D, De Luea F. Glucose tolerance, insulin secretion and peripheral sensitivity in thalassemia major. JPediatr Endocrinol Metab. 1998; supply 3:863-6
10. Torres FA, Bonduel M, Sciuccati G, et al. [Beta thalassemia major in Argentina]. Medicina (B Aires). 2002; 62 (2): 124-34.

11. Najafipour F. Evaluation of Endocrine Disorders in Patients with Thalassemia Major. Int $\mathrm{J}$ of Endocrinol Metab 2008; 2: 104-113.

12. Ikram N, Hassan k, Younas M, Amanat S. Ferritin Levels in Patients of Beta Thalassaemia Major. International Journal of Pathology; 2004; 2 (2): 71-74.

13. Lucas GN, Perera BJ, Fonseka EA, et al. De Silva DD, Fernandopulle M. A trial of deferiprone in transfusion-dependent iron overloaded children. Ceylon Med J. 2000 Jun;45(2):71-4.

14. Shah N, Mishra A, Chauhan D, et al. Study on effectiveness of transfusion program in thalassemia major patients receiving multiple blood transfusions at a transfusion centre in Western India. DOI:10.4103/09736247. 67029

15. Al Jaouni SK. Survival and disease complication of thalassemia major: Experience of 14 years at king Abdulaziz University Hospital, Jeddah, KSA. JKAU Med Sci 2010;17(1):19-28.doi: 10.4197/med. 17-1.3.

16. Cunningham MJ, Macklin EA, Neufeld EJ, et al. Thalassemia Clinical Research Network. Complications of beta-thalassemia major in North America. DOI:10. 1182/blood-2003-09-3167

17. Choudhry VP, Pati HP, Saxena A,et al. Deferiprone, efficacy and safety. Indian J Pediatr. 2004 Mar; 71(3):2136.

18. Riaz H, Riaz T, Khan MU, et al. Serum ferritin levels, socio-demographic factors and desferrioxamine therapy in multi-transfused thalassemia major patients at a government tertiary care hospital of Karachi, Pakistan. DOI:10. 1186/1756-0500-4-287

19. Rehman M and Lodhi Y. Prospects and future of conservative management of beta thalassaemia major in a developing country. Pak JMed Sci, 2004; 20 (2): $105-112$.

\section{How to cite this article?}

Koreti S, Gaur B.K, Das G, Gaur A. Study of Serum ferritin levels in $\beta$-Thalassemia major children. Int J Pediatr Res. 2018;5(6):308-313.doi:10.17511/ijpr.2018.i06.02. 